\title{
The Effect of Mentoring in the Public Sector
}

\author{
Jungin Kim*
}

\begin{abstract}
Using data from 1,220 public and nonprofit sector managers in Georgia and Illinois, this research assesses intrinsic and extrinsic motivation as predictors of job satisfaction in association with mentoring. Using analyses of ordinary least squares regression and structural equation modeling, statistically significant and positive relationships were found between intrinsic motivation and job satisfaction. The impact of extrinsic motivation on job satisfaction was found to vary. Job satisfaction was significantly and positively related to organizational trust but negatively related to economic benefit and risk-averse organizational values and goals. Furthermore, mentoring showed a mediating effect on the relationship between intrinsic and extrinsic motivation and job satisfaction. These findings suggest that mentoring in the public sector not only helps organizational members to develop their careers and to build better relationships with colleagues but also results in an increased relationship between job motivation and job satisfaction.
\end{abstract}

Keywords: intrinsic job motivation; extrinsic job motivation; mentoring; job satisfaction

\section{INTRODUCTION}

Since Homer wrote The Odyssey, the value of mentors in developing the talents of inexperienced young adults has been well documented in both the arts and the business world (e.g., Henderson, 1985; Klauss, 1981). In the realm of business, many studies have found that a mentor's multiple roles — such as parent figure, teacher, trusted advisor, and protector to an inexperienced young employee (Klauss, 1981)—are important in creating successful careers (Levinson, 1980; Lunding, Clements, \& Perkins, 1978; Roche, 1979). Additionally, these studies have found that employees who were in mentor relationships realized higher career achievement and indicated higher job satis-

\footnotetext{
* Jungin Kim is a senior researcher at Korea Human Resources Research Center. Her research interests include human resources policy, civil service reform, affirmative action, and equal employment opportunities. E-mail: jungink@gmail.com.
}

Manuscript received January 24, 2011; out for review February 28, 2011; review completed April 1, 2011; accepted April 3, 2011.

The Korean Journal of Policy Studies, Vol. 26, No. 1 (2011), pp. 97-115.

(C) 2011 by the GSPA, Seoul National University 
faction than those employees who did not have mentor relationships (Chao, Walz, \& Gardner, 1992; Murphy \& Ensher, 2001; Turban \& Dougherty, 1994). However, mentoring has not been rigorously studied in the field of public management, especially with respect to its impact on job satisfaction, which has been a focus of organizational studies (Henderson, 1985).

In addition, employee motivation and job satisfaction have been examined in organizational studies as they relate to certain organizational elements, but their relationship to mentoring remains unexplored. Because high employee motivation and job satisfaction tend to increase organizational commitment, analyses of these attributes are necessary in order to make an organizational diagnosis (Iverson, 1996; Morris, Lydka, \& O’Creevy, 1993; O’Driscoll \& Randall, 1999). Nevertheless, existing approaches to assessing the relationship between motivation and job satisfaction are insufficient because employees' psychological states are influenced by other working conditions such as work schedules and manager-subordinate relationships (Gakovic \& Tetrick, 2003; Jamal, 1981; Salzmann \& Grasha, 1991). In order to better capture these influences, the present study focuses on both employee motivation and job satisfaction as related to mentoring experiences.

Even though motivation generally increases employee job satisfaction, the relationship is likely to be differentiated according to employee mentoring experiences (Amabile, 1993; Savery, 1987; Bozeman and Feeney, 2008). For instance, if a supervisor sincerely instructs subordinates as a mentor, most subordinates will develop trust in the relationship as well as respect for the supervisor. Although employee work motivation and job satisfaction might increase as a result of these good relationships, negative mentoring relationships sometimes transpire (Amabile, 1993). Nonetheless, previous studies more often indicate that the degree of job satisfaction is likely to depend on whether organizational members have had a mentor or not (Chao et al., 1992; Fagenson, 1989). Bozeman and Feeney (2009) mainly focus on mentoring outcomes by including the concept of social capital in their mentoring research.

In this regard, this study assesses intrinsic motivation and extrinsic motivation as predictors of job satisfaction in association with the presence of mentoring using the National Administrative Studies Project (NASP) III data from public and nonprofit sector employees in Georgia and Illinois. It tests whether relationships between intrinsic and extrinsic motivation and job satisfaction are dependent on mentoring through ordinary least squares (OLS) regression and structural equation modeling. This study will provide evidence that mentoring is needed in Korean public organizations. 


\section{JOB MOTIVATION, JOB SATISFACTION, AND MENTORING}

Employee job motivation is primarily associated with the interaction between individuals and their work environments (Saleh \& Pasricha, 1975). Some scholars such as Klingner, Nalbandian, and Llorens (2010) argue that "motivation depends on how much an individual wants something relative to other things, and the perceived effortreward probability that they will get it" (p. 214). Intrinsic motivation is traditionally conceptualized as the need to fulfill one's potential (self-actualization) (Maslow, 1943); the need to investigate, explore, and master one's environment (Alderfer, 1972); and the internal desire to succeed (McClelland, 1961). Because intrinsic motivation is based on the assumption that "people need to feel competent," employees are intrinsically motivated when work environments increase feelings of competence and self-determination (Wiersma, 1992, p. 103). Klingner, Nalbandian, and Llorens (2010) assume that intrinsic motivation is associated with self-satisfaction or a sense of achievement (p. 215).

Extrinsic motivation, however, is associated with the model of job enrichment because employees are motivated by improved job skills, task identities, task significance, autonomy, and feedback (Hackman \& Oldham, 1976). Therefore, the components of extrinsic motivation are job-context factors such as salary, job security, relations with co-workers, and working conditions, including the organization's values, goals, rules, and procedures (Saleh \& Hyde, 1969). In other words, whereas intrinsic motivation is related to fulfillment of the needs for self-development and self-actualization, extrinsic motivation is associated with fulfillment of lower-order needs such as physiological, safety, and social needs (Maslow, 1943; Saleh \& Hyde, 1969).

Although many scholars and practitioners (e.g., Klingner, Nalbandian, and Llorens, 2010) believe that employees' motivation influences performance, they distinguish intrinsic and extrinsic motivations because the two concepts reflect different behaviors by individuals (Gagné \& Deci, 2005). In addition, an interaction effect occurs between intrinsic and extrinsic motivation because in some personality orientations, high levels of intrinsic motivation coexist with high levels of extrinsic motivation (Amabile, 1993). Most importantly, the distinction between intrinsic motivation as arising from the inherent value of work for the individual and extrinsic motivation as deriving from the desire to obtain outcomes apart from the work itself (Amabile, 1993) is meaningful for analyzing their impacts on employee job satisfaction as associated with employees' working conditions.

Because work motivation is generally associated with the process by which work behaviors are instigated, directed, sustained, and stopped, it is interactive between an individual and his or her work environment (Saleh \& Pasricha, 1975). Similarly, work 
motivation may influence the way employees feel about their work and their willingness to work (Amabile, 1993). Thus, employee satisfaction with intrinsic and extrinsic work rewards is closely tied to the extent to which employees commit affectively and are involved in their jobs (O'Driscoll \& Randall, 1999).

Job satisfaction depends significantly on the extent to which intrinsic and extrinsic motivation are consistent with the employee's motivational orientation toward work (Amabile, 1993). Of course, job satisfaction is recognized as a multidimensional construct. For example, the Minnesota Satisfaction Questionnaire viewed job satisfaction as involving four factors: working conditions, leadership, responsibility, and extrinsic rewards (Weiss, Dawis, England, \& Lofquist, 1967). Organizational factors such as diversification, formalization, and flexibility can also affect job satisfaction. Importantly, these organizational factors in turn influence intrinsic and extrinsic motivation (Smith \& Miner, 1983). Sometimes low job satisfaction among public employees may be related to a particular frustration like "lack of autonomy in some work settings due to rigid rules," which can be understood as the organizational rules factor of extrinsic motivation (Rainey \& Bozeman, 2000, p. 459).

In the field of management, a mentor is "a senior executive who can offer the wisdom of years of experience from which to counsel and guide younger individuals as they move ahead in their careers" (Klauss, 1981, 489). Mentoring increases valuable organizational outcomes (Aryee, Chay, \& Chew, 1994) as well as enhances the career development of the employees (Dreher \& Ash, 1990; Kram, 1983). In other words, employee mentoring experiences are closely tied to organizational outcomes such as job satisfaction, organizational commitment, and reduced turnover (Ragins \& Cotton, 1999; Seibert, 1999). Thus, employees who develop communication and problemsolving skills, which can be facilitated by mentors, tend to perceive the alignment of their jobs with the organizational mission and are satisfied with their jobs (Lankau \& Scandura, 2002).

Moreover, mentoring functions can contribute to greater job satisfaction and fulfillment by providing employees with insights and expectations (Ragins \& Scandura, 1994). Expectancy theory, which maintains that behavior arises from an individual's expectations about future consequences (Vecchio, 1991), substantiates this link (Klingner, Nalbandian, and Lloren, 2010). Employees' desire to fulfill expectations helps to enhance job satisfaction, because the process of meeting expectations renders the anticipated outcome a self-fulfilling prophecy. In this regard, employee mentoring experiences are positively associated with job satisfaction. For example, a field study of proteges involved in informal mentoring, formal mentoring, and non-mentorship programs found that they experienced increased job satisfaction given high levels of career-related or vocational tasks from their mentors (Chao et al., 1992). 
Thus, mentoring produces higher levels of job satisfaction by supplying proteges with more positive job experiences (Chao et al., 1992; Lankau \& Scandura, 2002; Murphy \& Ensher, 2001; Turban \& Dougherty, 1994; Whitely, Dougherty, \& Dreher, 1991) and with tangible personal benefits such as career mobility and opportunity, recognition, and promotion (Fagenson, 1989). Further, mentoring results in greater job satisfaction for proteges by alleviating negative experiences such as conflicts and stress (Bauch, Lankau, \& Scandura, 1996; Wilson \& Elmann, 1990). These individual benefits from mentoring are complemented by benefits at the organizational level via employee integration into organizational culture and norms (Burke, 1984) as well as through positive work commitment attitudes and lower turnover (Aryee \& Chay, 1994).

The effects of intrinsic and extrinsic motivation on job satisfaction differ according to the presence of mentoring experiences. Intrinsic and extrinsic motivation are positively associated with job satisfaction in that increased motivation positively influences the employee's perception of his or her job as well as the employee's willingness to work (Amabile, 1993). Employee mentoring experiences also contribute to high levels of career satisfaction, because mentoring encourages employees to further develop skills to advance their careers and to build positive relationships with colleagues, supervisors, and subordinates in the workplace (Chao et al., 1992; Murphy \& Ensher, 2001; Raabe \& Beehr, 2003; Turban \& Dougherty, 1994; Whitely et al., 1991). While intrinsic and extrinsic motivation play a meaningful role in job satisfaction, engagement in a mentoring experience offers a measurable benefit that enhances this level of satisfaction.

The link that mentoring provides between motivation and job satisfaction revolves around learning (Kram, 1985; Lankau \& Scandura, 2002). Job-related learning helps employees to understand the importance of their work, and this understanding is associated with increased satisfaction and motivation (Hackman \& Oldham, 1980). Because mentoring is a pivotal avenue for professional learning (Lankau \& Scandura, 2002), it can mediate the relationship between job motivation and job satisfaction. In addition, mentoring sustains characteristics not only of career-oriented functions such as coaching and sponsorship but also of psychosocial functions such as counseling, role modeling, affirmation, and friendship (Kram, 1985). As a result, mentoring affects the relationship between intrinsic motivation, which is characterized as employee career development and psychological composure, and employee job satisfaction.

The extrinsic motivation-job satisfaction relationship is also influenced by the presence of a mentoring relationship. Proteges who gain social support from their mentors are less likely to find alternative jobs and more likely to remain in same organization (Aryee et al., 1994; Scandura, 1992). On the other side, negative mentoring experiences 
lead proteges to leave their organization and engender psychological distress (Eby \& Allen, 2002). A negative mentor relationship is associated with negative protege pay and promotion, mismatched work-related values, lack of interpersonal relationship, and negative working conditions. Such negative experiences eventually influence job satisfaction detrimentally (Cranny, Smith, \& Stone, 1992; Eby \& Allen, 2002). The relationship between job motivation and job satisfaction will thus be mediated through mentoring.

Figure 1. Research Framew ork

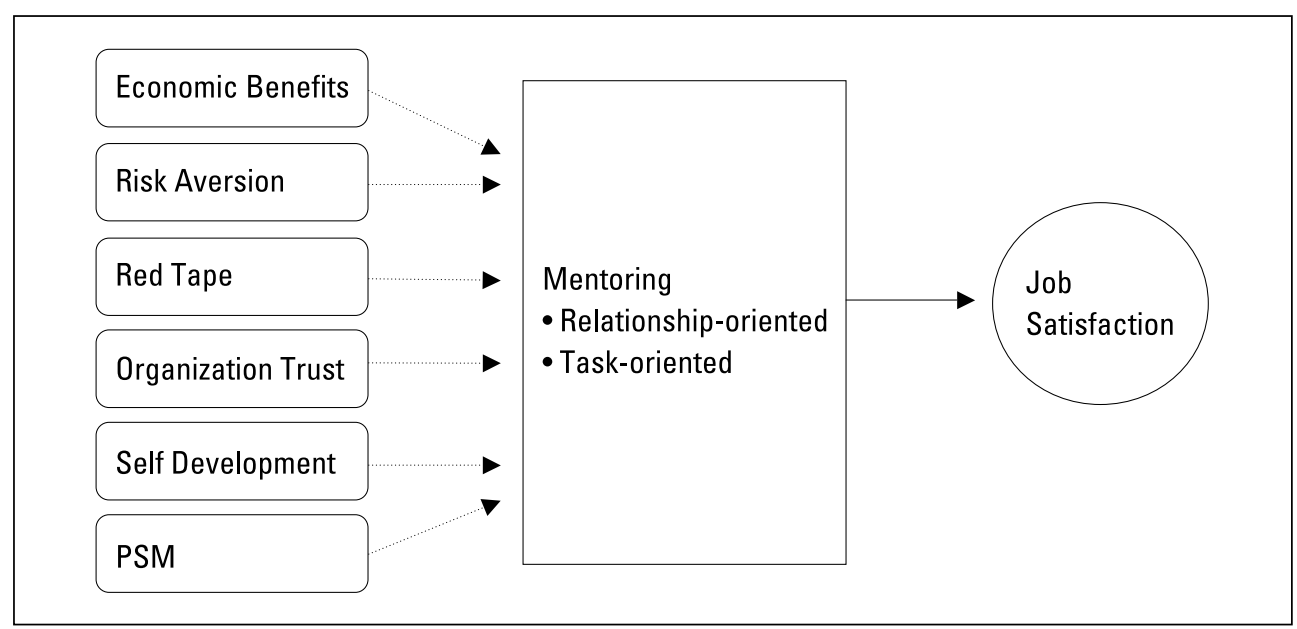

\section{METHODOLOGY}

\section{Sample and Procedures}

To investigate the career trajectories, attitudes, and perceptions of managers in the public and nonprofit sectors, NASP III included surveys of multiple agencies, state managers, and nonprofit managers in both Georgia and Illinois within the periods of wave I (September 23, 2005 to January 19, 2006), wave II (October 24, 2005 to February 20, 2006) and wave III (March 29, 2006 to June 1, 2006). In NASP III, the population for public employees in Georgia and Illinois was defined as managers, who are people paid above the pay grade 017; professionals; and public employees who are not employed in the office of the governor, judicial branch, commissions, or authorities in organizations with more than 60 employees. The population for nonprofit managers in Georgia and Illinois was defined as people who are in organizations with more than 20 
employees (Feeney, 2006).

The final response totaled 790 public-sector participants (about 43 percent), including 432 people from Georgia and 358 people from Illinois, and 430 nonprofit-sector participants (about 33 percent), including 107 people from Georgia and 323 people from Illinois. Participants who turned in the 1,220 usable questionnaires had an average age of 49.44 years at the time the questionnaire was administered ( $\mathrm{SD}=8.913$ years); 55 percent were male and 45 percent female.

The data in NASP III have some limitations in terms of the sampling. Since the nonprofit sample is not random and nonprofit managers are high-ranking managers, it is difficult to draw a comparison between the public and nonprofit sectors without testing for representativeness. For this reason, the present study could not accurately identify the differences between employee job satisfaction in the public and nonprofit sectors. Despite this limitation of generalizability due to restricted sample, this research is meaningful in terms of investigating the mediating effects of mentoring on the relationships between motivation and job satisfaction.

\section{Measures}

Intrinsic motivation, as one of two independent variables, was represented in two ways: self-development and public service motivation. First, self-development was used because employees are intrinsically motivated when their work environments increase their feelings of competence and self-determination (Wiersma, 1992). Measures of intrinsic motivation in terms of self-development included opportunity for advancement within the organization's hierarchy and opportunity for training and career development using a four-point scale (4 = strongly agree, $3=$ agree somewhat, 2 = disagree somewhat, 1 = strongly disagree), based on London and Smither's study in 1999 . The alpha reliability was 0.695 . Second, public service motivation was considered because serving the public or public causes can be an important aspect of selfactualization to public employees (Perry, 1996; Perry, Brudney, Coursey, and Littlepage, 2008). This item was measured according to the importance of the ability to serve the public and the public interest ( 4 = very important, $3=$ somewhat important, 2 $=$ somewhat unimportant, $1=$ not important).

Extrinsic motivation, the other independent variable, is related to job-context factors such as salary, job security, relations with coworkers, and working conditions (Saleh \& Hyde, 1969). Extrinsic motivation consists of four parts: economic benefit, risk-averse organizational values and goals, rules and procedures including red tape, and organizational trust. In particular, this research considered four extrinsic motivations: economic benefit and three organizational factors - organizational values, procedures, and trust. 
The items in each extrinsic motivation measure were modified based on previous studies.

Economic benefit, based on Bellante and Porter (1990), Morris et al. (1993), and Peiro, Garcia-Montalvo, and Gracia (2002), was measured using a four-point scale (4 $=$ very important, $3=$ somewhat important, $2=$ somewhat unimportant, $1=$ not important) that asked about the perceived importance of job security, the organization's pension or retirement plan, benefits (medical and insurance), salary, and employment opportunities for spouse or partner. However, the item regarding employment opportunities for spouse or partner was removed because of its low factor loading score. The alpha reliability among the four items was 0.734 .

Risk-averse organizational values and goals were measured with respect to the risk-averse behavior of both employees and top management using a four-point scale ( 4 = strongly agree, 3 = agree somewhat, 2 = disagree somewhat, $1=$ strongly disagree), based on Bozeman and Kingsley's 1998 study and Scott and Walsham's 2005 study. The alpha reliability was 0.634 . Rules and procedures including red tape were identified as the level of red tape in the organization using a 10-point scale following the item developed by Pandey and Scott (2002). Organizational trust was operationalized in terms of organizational members' pride and trust. This variable was measured using a four-point scale ( 4 = strongly agree, 3 = agree somewhat, 2 = disagree somewhat, 1 = strongly disagree) for two items based on previous research regarding organizational trust: the manager's sense of pride in working for the organization and top management's display of a high level of trust in the organization's employees (Cook \& Wall, 1980). The alpha reliability among the two items was 0.693 .

Job satisfaction, as a dependent variable, was measured using five items: "I put forth my best effort to get the job done regardless of the difficulties," "time seems to drag while I am on the job" (reverse coding), "it has been hard for me to get very involved in my current job" (reverse coding), "I do extra work for my job that isn't really expected of me," and "all in all, I am satisfied with my job." These items were measured using a four-point scale ( $4=$ strongly agree, $3=$ agree somewhat, $2=$ disagree somewhat, 1 = strongly disagree), and job satisfaction displayed an alpha reliability of 0.673 .

Employee mentoring, as a mediating variable, was constructed with respect to supervisory mentoring rather than peer mentoring in two parts: relationship-oriented mentoring and task-oriented mentoring. It was measured using a four-point scale (4 = strongly agree, 3 = agree somewhat, 2 = disagree somewhat, 1 = strongly disagree). Relationship-oriented mentoring included five items: professional values, friendship between mentor and employee, mutual respect of mentor and employee for each other's ideas, and consistency of the mentoring relationship. Task-oriented mentoring 
consisted of four items: the mentor's effort to introduce the protege to influential people inside and outside, the mentor's help in dealing with office politics, and the mentor's contribution to employee success. The alpha reliability of relationship-oriented mentoring was 0.767 and that of task-oriented mentoring was 0.685 .

Further explanation of the items noted above using varimax factor analysis is provided in the appendix.

\section{FINDINGS}

Table 1 provides the mean, standard deviation, and correlation for all variables. The dependent variable of job satisfaction in public and nonprofit managers in Georgia and Illinois was positively correlated with organizational trust $(\mathrm{r}=0.513, p<0.01)$, relationship-oriented mentoring $(\mathrm{r}=0.222, p<0.01)$, and task-oriented mentoring $(\mathrm{r}=$ $0.131, p<0.01)$, but negatively correlated with economic benefit $(\mathrm{r}=-0.101, p<$ $0.01)$, risk-averse organizational values and goals $(\mathrm{r}=-0.337, p<0.01)$, and rules and procedures including red tape $(\mathrm{r}=-0.319, p<0.01)$. The most unexpected finding of a

Table 1. Descriptive Statistics: M ean, Standard Deviation, Reliability, and Correlation

\begin{tabular}{|c|c|c|c|c|c|c|c|c|c|c|c|c|c|}
\hline & $M$ in & Max & Mean & SD & 1 & 2 & 3 & 4 & 5 & 6 & 7 & 8 & 9 \\
\hline $\begin{array}{l}\text { Self- } \\
\text { development }\end{array}$ & 2 & 8 & 6.03 & 1.66 & $(0.695)$ & & & & & & & & \\
\hline $\begin{array}{l}\text { Public service } \\
\text { motivation }\end{array}$ & 1 & 4 & 3.16 & 0.91 & $0.131^{* *}$ & & & & & & & & \\
\hline $\begin{array}{l}\text { Economic } \\
\text { benefit }\end{array}$ & 4 & 16 & 12.99 & 2.56 & $0.383^{* *}$ & $0.063 *$ & $(0.734)$ & & & & & & \\
\hline Risk aversion & 2 & 8 & 4.99 & 1.50 & 0.009 & -0.004 & $0.162^{* *}$ & $(0.634)$ & & & & & \\
\hline Red tape & 0 & 10 & 6.03 & 2.68 & $0.103^{* *}$ & 0.056 & $0.232 * *$ & $0.547^{* *}$ & & & & & \\
\hline $\begin{array}{l}\text { Organizational } \\
\text { trust }\end{array}$ & 2 & 8 & 6.22 & 1.53 & 0.148 & $0.079 * *$ & $-0.118^{* *}$ & $-0.555^{* *}$ & $-0.573^{* *}$ & $(0.693)$ & & & \\
\hline $\begin{array}{l}\text { J ob } \\
\text { satisfaction }\end{array}$ & 6 & 20 & 17.61 & 2.29 & 0.046 & $0.115^{* *}$ & $-0.115^{* *}$ & $-0.337^{* *}$ & $-0.319 * *$ & $0.513^{* *}$ & $(0.673)$ & & \\
\hline $\begin{array}{l}\text { Relationship- } \\
\text { oriented } \\
\text { mentoring }\end{array}$ & 7 & 20 & 18.08 & 2.16 & 0.059 & $0.130 * *$ & -0.038 & $-0.150^{* *}$ & $-0.097^{*}$ & $0.187^{* *}$ & $0.222^{* *}$ & $(0.767)$ & \\
\hline $\begin{array}{l}\text { Task-oriented } \\
\text { mentoring }\end{array}$ & 4 & 16 & 12.52 & 2.68 & 0.056 & $0.118^{* *}$ & -0.039 & $-0.113^{* *}$ & -0.048 & $0.120^{* *}$ & $0.131^{* *}$ & $0.448^{* *}$ & $(0.685)$ \\
\hline
\end{tabular}

Note: Alpha reliabilities are show $n$ in parentheses on the diagonal.

$* p<0.05$ (two-tailed test)

$* * p<0.01$ (two-tailed test) 
simple correlation matrix was that economic benefit was positively associated with risk-averse organizational values and goals, and rules and procedures including red tape, but negatively associated with organizational trust and job satisfaction.

For estimating all models, this research used OLS regression and structural equation modeling to measure causal relationships among variables (Wright, 1921). For testing the relationships among intrinsic and extrinsic motivation, relationship-oriented and task-oriented mentoring, and job satisfaction, this research concentrated primarily on OLS (see table 2). Step 1 included only the extrinsic motivation variables; step 2 added the intrinsic motivation variables; and finally, relationship-oriented and task-oriented mentoring variables were added in step 3.

Among the extrinsic motivation variables, organizational trust had a significant positive relationship with job satisfaction in all steps, but rules and procedures including red tape had no significant relationship with job satisfaction in any steps. In addition, risk-averse organizational values and goals, which were negatively related to job satisfaction in steps 1 and 2, became insignificant when mentoring was considered (see step 3). The most interesting result regarding extrinsic motivation was that economic benefit was significantly and negatively related to job satisfaction in all steps. In addition, intrinsic motivation, including both public service motivation and selfdevelopment, had a positive relationship with job satisfaction (see steps 2 and 3), and

Table 2. Regression Analysis of Variables Predicting J ob Satisfaction

\begin{tabular}{l|c|c|c|c|c|c}
\hline \multirow{2}{*}{ Variable } & \multicolumn{6}{c}{ Unstandardized coefficient } \\
\cline { 2 - 8 } & \multicolumn{2}{|c|}{ Step 1 } & \multicolumn{2}{c}{ Step 2 } & \multicolumn{2}{c}{ Step 3 } \\
\hline Economic benefit & $-0.044^{*}$ & $(0.023)$ & $-0.061^{* *}$ & $(0.025)$ & $-0.063^{*}$ & $(0.034)$ \\
\hline Risk aversion & $-0.096^{*}$ & $(0.049)$ & $-0.087^{*}$ & $(0.049)$ & -0.040 & $(0.065)$ \\
\hline Red tape & -0.004 & $(0.028)$ & 0.02 & $(0.029)$ & -0.025 & $(0.038)$ \\
\hline Organizational trust & $0.702^{* * *}$ & $(0.049)$ & $0.676^{* * *}$ & $(0.050)$ & $0.646^{* * *}$ & $(0.067)$ \\
\hline Self-development & & & $0.064^{*}$ & $(0.038)$ & $0.091^{*}$ & $(0.055)$ \\
\hline Public service motivation & & & $0.180^{* * *}$ & $(0.065)$ & $0.181^{* *}$ & $(0.091)$ \\
\hline Relationship-oriented mentoring & & & & & $0.133^{* * *}$ & $(0.041)$ \\
\hline Task-oriented mentoring & & & & & -0.013 & $(0.033)$ \\
\hline Constant & $14.25^{* * *}$ & $(0.552)$ & $13.568^{* * *}$ & $(0.581)$ & $11.215^{* * *}$ & $(0.996)$ \\
\hline R2 & 0.265 & & 0.273 & & 0.283 & \\
\hline F statistics & $103.64^{* * *}$ & $71.01^{* * *}$ & $28.5^{* * *}$ & \\
\hline
\end{tabular}

Note: Standard errors are in parentheses.

$* p<0.1$ (two-tailed test)

$* * p<0.05$ (tw 0 -tailed test)

$* * * p<0.01$ (two-tailed test) 
relationship-oriented mentoring was positively related to job satisfaction (see step 3).

The mediating effect of mentoring between intrinsic and extrinsic motivation and job satisfaction was tested using structural equation modeling. Figure 2 represents a full mediating model, specifying paths from intrinsic and extrinsic motivation to mentoring and from mentoring to job satisfaction. This model did not include direct paths from intrinsic and extrinsic motivation to job satisfaction. The fitness of model was as follows: $\left(X^{2}=427.84, d f=24, X^{2} / d f=17.82, p<0.01\right)$. This result supported the mediating effect of mentoring in the relationship between motivation and job satisfaction. However, although the intrinsic motivation factor, consisting of self-development and public service motivation, was positively related to mentoring $(\beta=0.359, p<0.01)$ and mentoring showed a positive relationship to job satisfaction $(\beta=0.691, p<0.01)$, the extrinsic motivation factor was negatively related to mentoring $(\beta=-0.749, p<0.01)$. Finally, no significant correlation existed between intrinsic and extrinsic motivation $(ß=-0.014, p>0.1)$.

Figure 2. Results of Structural Equation M odeling on the M ediating Effect of M entoring

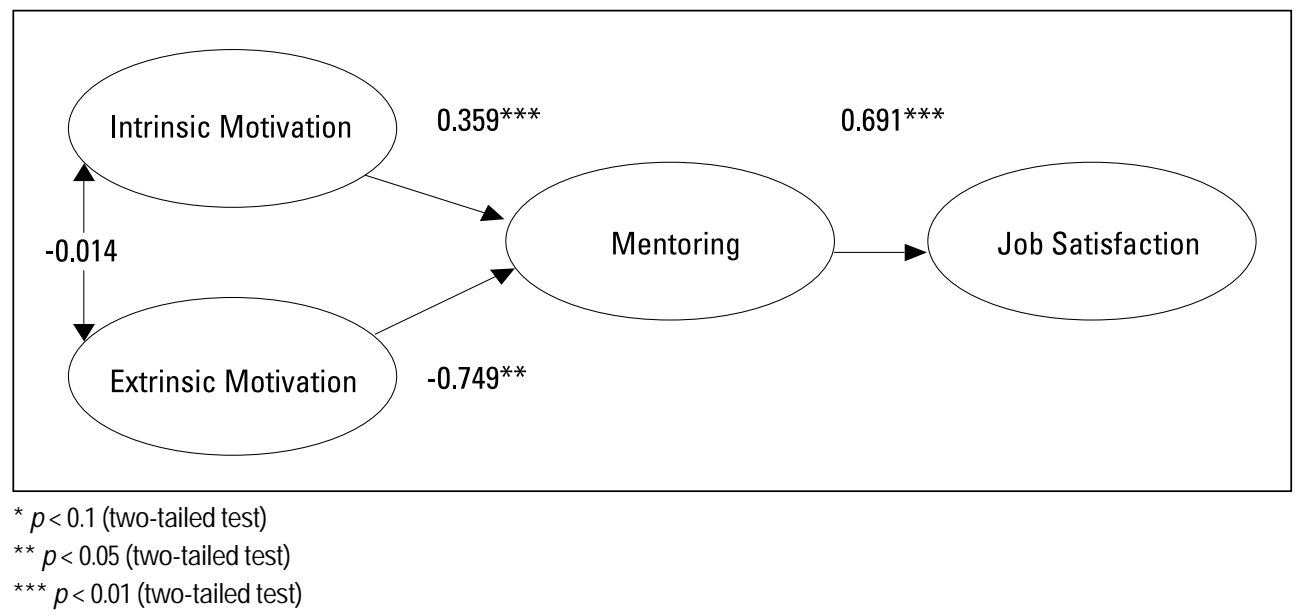

\section{DISCUSSION AND CONCLUSION}

As noted in the Hawthorne studies of the 1930s, psychological factors play a primary role in organizational life (Schott, 1986). Organizational members are anxious to pursue self-development, and public employees are particularly proud of their public sector service. Therefore, they are intrinsically motivated and satisfied with working for their organizations when they perceive the opportunity to develop their careers and 
when they perceive the importance of publicness in their organizations. This research empirically supports the vital implications of intrinsic motivation in public and nonprofit managers. When managers had the opportunity for advancement, training, and career development and valued the ability to serve the public and the public interest, they demonstrated job satisfaction by doing extra work and by putting forth their best efforts.

In contrast to the impact of intrinsic motivation, extrinsic motivation had different effects on job satisfaction according to the item measured. The most interesting result was the negative impact of economic benefit motivation. In all regression models (see table 2), managers in the public and non-profit sectors showed dysfunctional effects of economic benefits such as salary, job security, pension or retirement plan, and other benefits (medical and insurance) on their job satisfaction. This result may come from the sample characteristics in this research. The average salary of participants was $\$ 68,754$, and they were above pay grade 017 . As a result, increased economic benefits might not be a major concern to them. Low variance among salaries and pay grades might also explain this finding.

As other sources of extrinsic motivation, organizational context elements such as organizational red tape, organizational trust, and risk-averse organizational attitudes showed varied influence on job satisfaction. The degree of perceived red tape within an organization had no significant impact on job satisfaction. However, according to the correlation table, red tape had a strongly negative correlation with job satisfaction (see table 1). This negative implication of red tape is consistent with previous research, which surveyed managers in state health and human service agencies in the National Administrative Studies Project (NASP-II). Dehart-Davis and Pandey (2005) supported these results by stating that perceived personnel red tape reduced organizational commitment and job involvement, thereby having a negative effect on job satisfaction. In addition, the positive impact of organizational trust on job satisfaction implies that employees are satisfied with their jobs when they perceive a high degree of organizational trust based on task feedback, supportive leadership, participatory decision making processes, and similar qualities (Podsakoff, MacKenzie, \& Bommer, 1996).

Most of all, the relationship between intrinsic and extrinsic motivation and job satisfaction is differentiated depending on the existence of mentoring experiences. This research illustrates the positive mediating effects of mentoring. When the mentoring relationship is friendly, based on mutual respect and similar values, and contributes to the protege's success, mentoring can play a pivotal role in the relationship between motivation and job satisfaction.

These results are consistent with findings from previous studies regarding mentoring, job satisfaction, and motivation, which state that employees are satisfied with their 
jobs when mentors offer them high levels of career-related development associated with self-development (Chao et al., 1992). That is, mentoring experiences not only help employees to develop their careers and to build better relationships with colleagues (Chao et al., 1992; Whitely et al., 1991), but they also result in increased motivation when employees receive high levels of counseling and coaching from their mentors (Fine \& Pullins, 1998). In particular, self-development (an intrinsic motivation that positively affects job satisfaction of employees with mentoring experiences) is closely tied with mentoring in that employees are intrinsically motivated when their work environments increase feelings of competence and self-determination (Wiersma, 1992). Thus, such a finding in the present study implies that employee mentoring positively mediates a relationship between motivation and job satisfaction.

In this regard, some managerial implications are suggested as well. Most of all, mentoring systems appear important if an organization wishes to increase employee motivation and satisfaction. A mentoring system between supervisors and subordinates may improve leader-subordinate relationships, and a peer mentoring system may help employees to better understand their working conditions. Thus, employee motivation and satisfaction will be increased in the presence of mentoring systems. Mentoring can be utilized to increase public management professionalism. Mentoring can also increase organizational efficiency in that mentors tend to possess years of professional experience, which can prove useful in counseling and guiding younger or less experienced employees along their career paths.

This study addressed the importance of intrinsic and extrinsic motivation to organizational members' job satisfaction and the mediating effect of mentoring using NASP III data from public and nonprofit sector managers in Georgia and Illinois. It found that intrinsic motivation (self-development and public service motivation) was positively related to job satisfaction. Regarding extrinsic motivation, organizational members were satisfied when they were surrounded with high levels of organizational trust and risk-taking organizational values and goals. However, they were less satisfied in conditions of high levels of economic benefit, and no significant relationship was found between job satisfaction and rules and procedures including red tape. Nevertheless, mentoring enacted an important mediating effect on the relationship between motivation and job satisfaction.

In Korea, some research has examined the different effects of mentoring in the public and private sectors. In particular, Kim and Ha's 2007 study attempted to identify implications for utilizing mentoring systems in Korean public organizations. It found that scholars and practitioners in the public administration and policy field are concerned about mentoring as a way of improving productivity and efficiency in public organizations by restructuring the relationships between managers and subordinators. 
In this regard, the present study provided evidence that mentoring can influence employees' motivation and job satisfaction, and that utilizing mentoring systems in public organizations is important. Overall, this study contributed to developing theoretical and empirical guidelines for creating a productive and efficient organizational culture by facilitating relationship-oriented mentoring systems.

\section{APPENDIX}

Table A-1. Factor Analysis Using Varimax Rotation Techniques

\begin{tabular}{|c|c|c|}
\hline & Item & Factor loading score \\
\hline \multirow{3}{*}{ Self-development } & $\begin{array}{l}\text { Opportunity for advancement within the organization's } \\
\text { hierarchy }\end{array}$ & 0.877 \\
\hline & Opportunity for training and career development & 0.877 \\
\hline & Reliability & Cronbach's alpha (0.695) \\
\hline \multirow{6}{*}{ Economic benefit } & J ob security & 0.737 \\
\hline & The organization's pension or retirement plan & 0.845 \\
\hline & Benefits (medical, insurance) & 0.862 \\
\hline & Employment opportunities for spouse or partner & 0.308 \\
\hline & Salary & 0.491 \\
\hline & Reliability & Cronbach's alpha (0.734) \\
\hline \multirow{3}{*}{$\begin{array}{l}\text { Risk-averse } \\
\text { organizational } \\
\text { values and goals }\end{array}$} & Employees in this organization are afraid to take risks & 0.856 \\
\hline & Top management in this organization is afraid to take risks & 0.856 \\
\hline & Reliability & Cronbach's alpha (0.634) \\
\hline \multirow{3}{*}{$\begin{array}{l}\text { Organizational } \\
\text { trust }\end{array}$} & I feel a sense of pride working for this organization & 0.879 \\
\hline & $\begin{array}{l}\text { Top management displays a high level of trust in this } \\
\text { organization's employees }\end{array}$ & 0.879 \\
\hline & Reliability & Cronbach's alpha (0.693) \\
\hline \multirow{6}{*}{$\begin{array}{l}\text { Relationship- } \\
\text { oriented } \\
\text { mentoring }\end{array}$} & My mentor and I share similar professional values & 0.694 \\
\hline & My mentor and $I$ are friends & 0.720 \\
\hline & My mentor has a great deal of respect for my ideas & 0.739 \\
\hline & I have a great deal of respect for my mentor's ideas & 0.805 \\
\hline & $\begin{array}{l}\text { If I had to do it over again, I would be reluctant to have this } \\
\text { person as a mentor (reverse coding) }\end{array}$ & 0.681 \\
\hline & Reliability & Cronbach's alpha (0.767) \\
\hline
\end{tabular}




\begin{tabular}{l|l|l}
\hline & Item & Factor loading score \\
\hline \multirow{4}{*}{$\begin{array}{l}\text { Task-oriented } \\
\text { mentoring }\end{array}$} & $\begin{array}{l}\text { My mentor helped introduce me to influential people in this } \\
\text { organization }\end{array}$ & 0.786 \\
\cline { 2 - 3 } & $\begin{array}{l}\text { My mentor helped introduce me to influential people outside } \\
\text { this organization }\end{array}$ & 0.679 \\
\cline { 2 - 3 } & My mentor has helped me deal with "office politics" & 0.672 \\
\cline { 2 - 3 } & $\begin{array}{l}\text { Overall, my mentor has contributed a great deal to my } \\
\text { success in this organization }\end{array}$ & 0.744 \\
\cline { 2 - 3 } & Reliability & Cronbach's alpha (0.685) \\
\hline \multirow{5}{*}{ J ob satisfaction } & $\begin{array}{l}\text { I put forth my best effort to get the job done regardless of } \\
\text { the difficulties }\end{array}$ & 0.586 \\
\cline { 2 - 3 } & Time seems to drag while I am on the job (reverse coding) & 0.777 \\
\cline { 2 - 3 } & $\begin{array}{l}\text { It has been hard for me to get very involved in my current } \\
\text { job (reverse coding) }\end{array}$ & 0.790 \\
\cline { 2 - 3 } & I do extra work for my job that isn't really expected of me & 0.473 \\
\cline { 2 - 3 } & All in all, I am satisfied with my job & 0.691 \\
\cline { 2 - 3 } & Reliability & Cronbach's alpha (0.673) \\
\hline
\end{tabular}

\section{REFERENCES}

Alderfer, C. P. 1972. Existence, relatedness and growth. New York: The Free Press.

Amabile, T. M. 1993. Motivational synergy: Toward new conceptualizations of intrinsic and extrinsic motivation in the workplace. Human Resource Management Review, 3: $185-202$.

Aryee, S., \& Chay, Y. W. 1994. An examination of the impact of career-oriented mentoring on work commitment attitudes and career satisfaction among professional and managerial employees. British Journal of Management, 5: 241-250.

Aryee, S., Chay, Y. W., \& Chew, J. 1994. An investigation of the predictors and outcomes of career commitment in three career stages. Journal of Vocational Behavior, 44: 1-16.

Bauch, S. G., Lankau, M., \& Scandura, T. A. 1996. An investigation of the effects of protege gender on responses to mentoring. Journal of Vocational Behavior, 49: 309-323.

Bellante, D., \& Porter, P. K. 1990. A subjectivist economic analysis of governmentmandated employee benefits. Harvard Journal of Law and Public Policy, 13: 657-688. 
Bozeman, B., \& Feeney, M. K. 2008. Mentor matching: A "goodness of fit" model. Administration \& Society, 9: 1-18.

Bozeman, B., \& Feeney, M. K. 2009. Public management mentoring: What affects outcomes? Journal of Public Administration Research and Theory, 19(2): 427452.

Bozeman, B., \& Kingsley, G. 1998. Risk culture in public and private organizations. Public Administration Review, 58: 109-118.

Burke, R. 1984. Mentoring in organizations. Group and Organization Studies, 9: 353372.

Chao, G. T., Walz, P. M., \& Gardner, P. D. 1992. Formal and informal mentorships: A comparison on mentoring functions and contrast with nonmentored counterparts. Personnel Psychology, 45: 619-636.

Cook, J., \& Wall, T. 1980. New work attitude measures of trust, organizational commitment and personal need non-fulfillment. Journal of Occupational Psychology, 53: 39-52.

Cranny, C. J., Smith, P. C., \& Stone, E. F. 1992. Job satisfaction. New York: Lexington.

Dehart-Davis, L., \& Pandey, S. K. 2005. Red tape and public employees: Does perceived rule dysfunction alienate managers? Journal of Public Administration Research and Theory, 15: 133-148.

Dreher, G. F., \& Ash, R. A. 1990. A comparative study of mentoring among men and women in managerial, professional, and technical positions. Journal of Applied Psychology, 75: 539-596.

Eby, L., \& Allen, T. 2002. Further investigation of proteges' negative mentoring experiences. Group and Organization Management, 27: 456-479.

Fagenson, E. A. 1989. The mentor advantage: Perceived career/job experiences of proteges versus non-proteges. Journal of Organizational Behavior, 10: 309-320.

Feeney, M. K. 2006. NASP III: Research design and data description. Georgia Institute of Technology

Fine, L. M., \& Pullins, E. B. 1998. Peer mentoring in the industrial sales force: An exploratory investigation of men and women in developmental relationships. Journal of Personal Selling and Sales Management, 18: 89-103.

Gagné, M., \& Deci, E. L. 2005. Self-determination theory and work motivation. Journal of Organizational Behavior, 26: 331-362.

Gakovic, A., \& Tetrick, L. E. 2003. Perceived organizational support and work status: A comparison of the employment relationships of part-time and full-time employees attending university classes. Journal of Organizational Behavior, 24: 649-667. 
Hackman, R. J., \& Oldham, G. R. 1976. Motivation through the design of work. Organizational Behavior and Human Performance, 16: 250-279. . 1980. Work redesign. Reading, MA: Addison-Wesley.

Henderson, D. W. 1985. Enlightened mentoring: A characteristics of public management professionalism. Public Administration Review, 45: 857-863.

Iverson, R. D. 1996. Employee acceptance of organizational change: The role of organizational commitment. The International Journal of Human Resource Management, 7: 122-149.

Jamal, M. 1981. Shift work related to job attitudes, social participation and withdrawal behavior: A study of nurses and industrial workers. Personnel Psychology, 34: 535-547.

Kim, W. S., \& Ha, M. C. 2007. Differences mentoring effects between public and private organizations. Korean Society and Public Administration, 18(2): 99-120.

Klauss, R. 1981. Formalized mentor relationships for management and executive development programs in the federal government. Public Administration Review, 41: 489-496.

Klingner, D. E., Nalbandian, J., \& Lloren, J. 2010. Public personnel management: Contexts and strategies, 6th ed. Longman: New York

Kram, K. E. 1983. Phases of the mentor relationship. Academy of Management Journal, 26: 608-625.

Kram, K. E. 1985. Mentoring at work: Developmental relationship in organizational life. Glenview, IL: Scott, Foresman and Company.

Lankau, M. J., \& Scandura, T. A. 2002. An investigation of personal learning in mentoring relationships: Content, antecedents, and consequences. Academy of Management Journal, 45: 779-790.

Levinson, H. 1980. Criteria for choosing chief executives. Harvard Business Review, 58: 114-120.

Lunding, F. J., Clements, G. E., \& Perkins, D. S. 1978. Everyone who makes it has a mentor. Harvard Business Review, 56: 89-101.

Maslow, A. H. 1943. A theory of human motivation. Psychological Review, 50: 370396.

McClelland, D. C. 1961. The achieving society. Princeton, NJ: Van Nostrand.

Morris, T., Lydka, H., \& O’Creevy, M. F. 1993. Can commitment be managed? A longitudinal analysis of employee commitment and human resource policies. Human Resource Management Journal, 3: 21-42.

Murphy, S., \& Ensher, E. 2001. The role of mentoring support and self-management strategies on reported career outcomes. Journal of Career Development, 27: 229-246. 
O’Driscoll, M. P., \& Randall, D. M. 1999. Perceived organizational support, satisfaction with rewards, and employee job involvement and organizational commitment. Applied Psychology: An International Review, 48: 197-209.

Pandey, S. K., \& Scott, P. G. 2002. Red tape: A review and assessment of concepts and measures. Journal of Public Administration Research and Theory, 12: 553-581.

Peiró, J. M., Garcia-Montalvo, J., \& Gracia, F. 2002. How do young people cope with job flexibility?: Demographic and psychological antecedents of the resistance to accept a job with non-preferred flexibility features. Applied Psychology: An International Review, 51: 43-67.

Perry, J. L. 1996. Measuring public service motivation: An assessment of construct reliability and validity. Journal of Public Administration Research and Theory, 6: 5-24.

Perry, J. L., Brudney, J. L., Coursey, D., and Littlepage, L. 2008. What drives morally committed citizens? A study of the antecedents of public service motivation. Public Administration Review, 68(3): 445-458.

Podsakoff, P. M., MacKenzie, S. B., \& Bommer, W. H. 1996. Transformational leader behaviors and substitutes for leadership as determinants of employee satisfaction, commitment, trust, and organizational citizenship behaviors. Journal of Management, 22: 259-299.

Raabe, B., \& Beehr, T. A. 2003. Formal mentoring versus supervisor and coworker relationships: Differences in perceptions and impact. Journal of Organizational Behavior, 24: 271-294.

Ragins, B. R., \& Cotton, J. L. 1999. Mentor functions and outcomes: A comparison of men and women in formal and informal mentoring relationships. Journal of Applied Psychology, 84: 529-550.

Ragins, B. R., \& Scandura, T. A. 1994. Gender differences in expected outcomes of mentoring relationships. Academy of Management Journal, 37: 957-971.

Rainey, H. G., \& Bozeman, B. 2000. Comparing public and private organizations: Empirical research and the power of the a priori. Journal of Public Administration Research and Theory, 10: 447-469.

Roche, G. R. 1979. Much ado about mentors. Harvard Business Review, 57: 14-28.

Saleh, S. D., \& Hyde, J. 1969. Intrinsic vs. extrinsic orientation and job satisfaction. Occupational Psychology, 43: 47-53.

Saleh, S. D., \& Pasricha, V. 1975. Job orientation and work behavior. Academy of Management Journal, 18: 638-645.

Salzmann, J., \& Grasha, A. F. 1991. Psychological size and psychological distance in manager-subordinate relationships. Journal of Social Psychology, 131: 629-646.

Savery, L. K. 1987. Effect of motivators on job satisfaction. Journal of Managerial 
Psychology, 2: 28-32.

Scandura, T. A. 1992. Mentorship and career mobility: An empirical investigation. Journal of Organizational Behavior, 13: 169-174.

Schott, R. L. 1986. The psychological development of adults: Implications for public administration. Public Administration Review, 46: 657-667.

Scott, S. V., \& Walsham, G. 2005. Reconceptualizing and managing reputation risk in the knowledge economy: Toward reputable action. Organization Science, 16: 308-322.

Seibert, S. 1999. The effectiveness of facilitated mentoring: A longitudinal quasiexperiment. Journal of Vocational Behavior, 54: 483-502.

Smith, N. R., \& Miner, J. B. 1983. Type of entrepreneur, type of firm, and managerial motivation: Implications for organizational life cycle theory. Strategic Management Journal, 4: 325-340.

Turban, D. B., \& Dougherty, T. W. 1994. Role of protege personality in receipt of mentoring and career success. Academy of Management Journal, 37: 688-702.

Vecchio, R. V. 1991. Organizational behavior, 2nd ed. Chicago, IL: The Dryden Press.

Weiss, D., Dawis, R., England, G., \& Lofguist, L. 1967. Manual for the Minnesota satisfaction questionnaire (Minnesota Studies on Vocational Rehabilitation No. 22). Minneapolis, MN: University of Minnesota, Industrial Relations Center.

Whitely, W., Dougherty, T. W., \& Dreher, G. F. 1991. Relationship of career mentoring and socioeconomic origin to managers' and professionals' early career progress. Academy of Management Journal, 34: 331-351.

Wiersma, U. J. 1992. The effects of extrinsic rewards in intrinsic motivation: A metaanalysis. Journal of Occupational and Organizational Psychology, 65: 101-114.

Wilson, J. A., \& Elmann, N. S. 1990. Organizational benefits of mentoring. Academy of Management Executive, 4: 88-94.

Wright, S. S. 1921. Correlation of causation. Journal of Agricultural Research, 20: 557-585. 